\title{
A myoma uteri diagnosztikája és kezelése
}

\author{
Török Péter dr. - Póka Róbert dr.
}

Debreceni Egyetem, Klinikai Központ, Szülészeti és Nőgyógyászati Klinika, Debrecen

\begin{abstract}
A myoma a leggyakoribb nőgyógyászati jóindulatú daganat. Előfordulása rasszonként változó, általánosságban a reproduktív korú nők negyedét érinti. Rosszindulatú elfajulása az esetek kis részében észlelhető. Elhelyezkedésüktől, méretüktől függőon diverz panaszokat okoznak, a meddőségtől az életminőséget komolyan befolyásoló vérzészavarokig. A myoma felismerése, diagnosztikája a képalkotó módszerek és az endoszkópos beavatkozások egyre szélesebb körben való elterjedésének köszönhetően korai stádiumban lehetséges és igen nagy pontosságú. Kezelésük az általuk okozott panaszok súlyosságától függően szükséges. A terápiában gyógyszeres, radiológiai és sebészi módszerek is szerepet kapnak. A kezeléssel kapcsolatos kérdések az elmúlt évben igen nagy publicitást kaptak, az egyesült államokbeli „myomabotrány” miatt az eddiginél is szélesebb érdeklődés középpontjába kerültek. Orv. Hetil., 2016, 157(21), 813-819.
\end{abstract}

Kulcsszavak: myoma, vérzészavar, meddőség, endoszkópia

\section{Diagnosis and treatment of fibroids}

Uterine fibroid is the most common tumor in women of reproductive age. Depending on the size and location they can cause variety of symptoms. The clinical presentation may include bleeding disorders, infertility, pelvic pain and dysmenorrhea as well. Detection and precise evaluation of the number, size and location of myomas is possible due to advances in imaging and endoscopic methods. Treatment of fibroids depends on the severity and type of symptoms. There are medical, radiological and surgical options for treatment. Debates on fibroid management are widely published and are in focus recently, related to the "fibroid-scandal" occurred in the United States.

Keywords: fibroid, abnormal uterine bleeding, infertility, endoscopy

Török, P., Póka, R. [Diagnosis and treatment of fibroids]. Orv. Hetil., 2016, 157(21), 813-819.

(Beérkezett: 2016. február 24.; elfogadva: 2016. március 24.)

\section{Rövidítések}

FDA $=$ Food and Drug Administration; FIGO = International Federation of Gynecology and Obstetrics; GnRH = gonadotrop releasing hormon; HSC = hiszteroszkópia; HSG = hiszteroszalpingográfia; $\mathrm{JZ}=$ junctionalis zóna; $\mathrm{MRI}=$ mágneses rezonanciavizsgálat; PAECs $=$ progesterone receptor modulators-associated endometrial changes; SIS = szalinainfúziós ultrahangvizsgálat; SPRM = szelektív progeszteronreceptor-módosító; UPA = ulipristal acetát

A myoma uteri a méhfal simaizomzatának monoklonális jóindulatú daganata. Általában az ép myometriumtól jól elhatárolt, azonban önálló tokja nincsen. A kóreredet epigenetikai hátterének tisztázása még nem végleges, számos géneltérés vizsgálata folyamatban van [1]. Növekedésében a genetikai faktorokon túl biokémiai és hormonális faktorok is szerepet játszanak. A hosszú távú emelkedett ösztrogénexpozíció (elhízás, korai menarche) emeli, a csökkent expozíció (multiparitás) csökkenti a myoma előfordulását, amiből az ösztrogén befolyásolóhatására következtethetünk. A myoma magasabb progeszteron-A- és -B-receptor-koncentrációja és az, hogy a mitotikus aktivitás a szekréciós fázisban, a progeszterontermelés csúcsán figyelhető meg, a progeszteron szerepét igazolja. A myomák előfordulása pubertás előtt igen ritka, a fertilis korban emelkedett, menopausa után pedig 
csökken. Ezek az adatok szintén a hormonális hatást támasztják alá [2].

Malignalizálódásuk kétséges, genetikai különbözőségük azt veti fel, hogy a leiomyosarcoma nem myomaeredetű, nem a myoma rosszindulatú degenerációjának eredménye [3]. Myomának vélt elváltozások rosszindulatú szövettani lelete $0,14 \%$ gyakoriságú [4].

Elhelyezkedésüket tekintve többféle beosztás található az irodalomban, legszélesebb körben az International Federation of Gynecology and Obstetrics (FIGO) -beosztás a használatos (1. ábra). Azontúl, hogy a méh üregéhez viszonyítva hogy helyezkedik el a daganat, annak az endometriumhoz való viszonya is fontos tényező lehet. Az elhelyezkedést illetően újabb kutatások azt vizsgálják, hogy a junctionalis zónához viszonyítva hol helyezkedik el a myoma [5]. A junctionalis zónából kiinduló folyamatok a méh kontrakcióit nagymértékben módosítják, ami hatással lehet a spermium-, embriótranszportra, beágyazódásra, ezáltal szerepe lehet a meddőségben. Szintén szerepet tulajdonítanak az ilyen eredetű myomák menstruációra gyakorolt hatásának is. A junctionalis zóna daganatai egyéb összefüggésekben, az adenomyosis és az endometriosis kialakulásában is feltételezhető ok lehet.

Számos tanulmány foglalkozik a myoma prevalenciájával, incidenciájával; a közlések széles skálán, egész életre vonatkozóan 40-80\%-os értékekról számolnak be. A leiomyoma észlelése számos esetben véletlen lelet, a páciensek az esetek 50\%-ában tünet- és panaszmentesek, aminek következtében a valódi prevalencia magasabb [6]. A prevalencia kor- és népcsoportok szerint is eltéró. A 20 év alattiak között ritkábban tapasztalható, előfor-

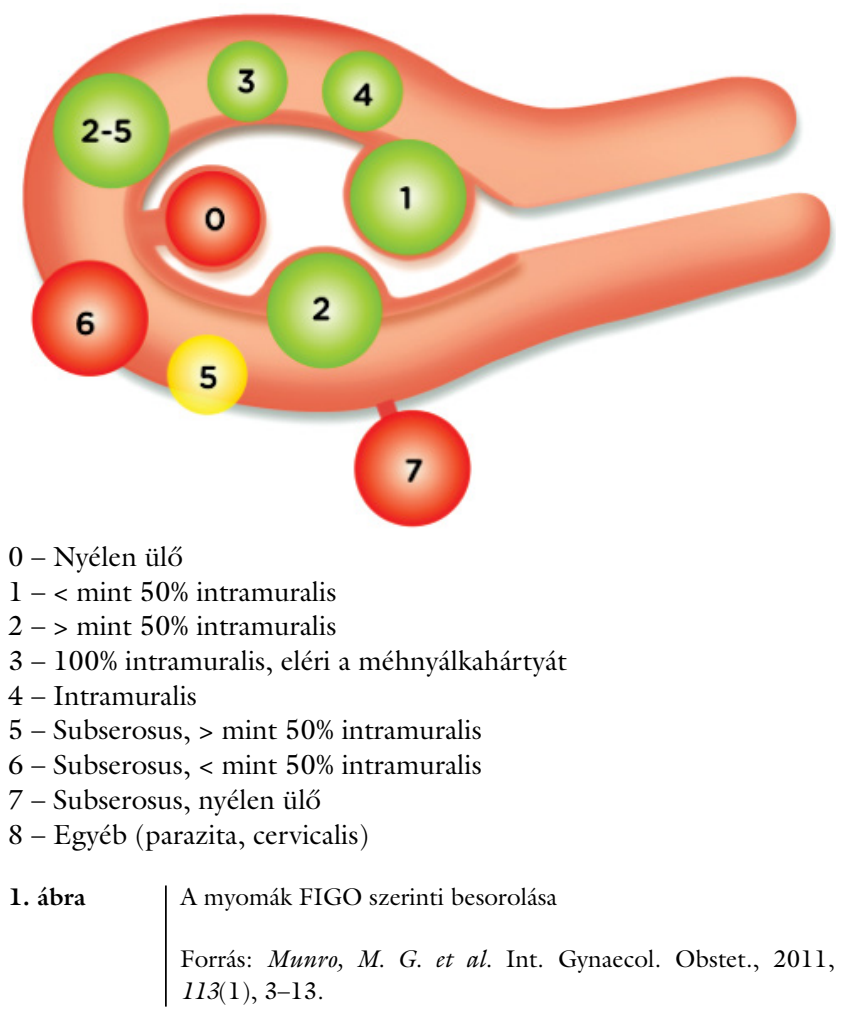

dulásuk az 50-es évekre éri el a csúcspontját. Az afrikai populációban jóval gyakoribb lelet mind a tünetmentes, mind a panaszos alcsoportban [7]. A prediszponáló tényezők között az alkohol- és kávéfogyasztás is megtalálható [8], míg a dohányzás a kialakulás esélyét csökkentheti [9]. A panaszok közül leggyakoribb a vérzészavar, meddőség, habituális vetélés, alhasi diszkomfort, vizelési, székelési problémák.

\section{Vérzészavar}

A vérzészavar az egyik leggyakoribb panasz a prae- és postmenopausában lévő myomás nők között. A panaszos betegek 30\%-a jelentkezik emiatt orvosnál. A panasz az enyhe, normálistól alig eltérő vérzéstől egészen a mindennapi tevékenység akadályozásán keresztül a következményes vérszegénységig széles skálán mozoghat. A vérzészavar lehet mennyiségi eltérés (menorrhagia) és időbeni eltérés (metrorrhagia) is. Ezen eltérések egyike sem specifikus a myomákra, bár leggyakrabban az elhúzódó, bő vérzés a jellemző [10]. A vérzészavar kialakulásának mechanizmusa egyértelmúen nem ismert. Összefüggésbe hozható a méh érellátásának megváltozásával, azzal, hogy a méhnyálkahártya a myoma fölött elvékonyodik, nem jó a vérellátása. Háttérben állhat a méh spontán kontrakcióinak befolyásolása is. A méhfalon belüli elhelyezkedés vizsgálatakor szorosabb összefüggés tapasztalható a vérzészavarok és a submucosus, illetve intramuralis típusok között, míg a subserosus myomák ritkábban okoznak ilyen jellegű problémákat. A topográfiai elhelyezkedés (mellső, hátsó fal) és a myomák száma nem mutat korrelációt a menstruációs eltérésekkel, de a myoma nagysága azokkal összefüggésbe hozható [11]. A korábban leírt hormonhatásnak felel meg az a kép is, miszerint ezek a vérzészavarok a menopausát követően csökkennek, a postmenopausalis hormonterápia hatására viszont fokozódik az előfordulásuk.

\section{Meddőség, habituális vetélés}

A steril nőbetegek 5-10\%-ánál fordul elő myoma, ezen páciensek 1-2,4\%-ánál ez az egyetlen eltérés [12]. Számos tanulmány foglalkozik a myomák fertilitásra, korai terhességre gyakorolt hatásával. A feltételezések szerteágazóak a mechanizmust illetően. A cervix, méhüreg torzításával akadályozhatják a spermiumtranszportot, a méhnyálkahártya idült gyulladását okozhatják, befolyásolva ezáltal az embrió megtapadását, de a méhfal kóros kontrakcióinak kialakulásában is részt vehetnek. A myomák a lombikprogramban szereplőknél is csökkentik a sikerességet, így a gamétatranszport akadályozása mellett más mechanizmusok is meghatározóak. Az ismételt vetélések hátterében is gyakran előfordul a myoma, ami szintén ezt az elméletet támasztja alá [13].

Elhelyezkedésükkel kapcsolatban a méhűr közelsége a meghatározó faktor. A submucosus gócok bírnak legnagyobb, míg a subserosus gócok a legkisebb szereppel. 
Áttekintő tanulmányok szignifikánsan alacsonyabb klinikai terhességi, beágyazódási és élveszületési ráta mellett szignifikánsabb magasabb spontán vetélési arányt találtak [14]. Submucosus lokalizációra fókuszálva, ezeknél az eseteknél szignifikánsan csökken a klinikai terhesség, beágyazódás, élveszületés gyakorisága, szignifikánsan nő a spontán vetélés esélye, ugyanakkor a koraszülés gyakorisága nem változik. Az intramuralis gócok vizsgálatánál hasonlóak az eredmények. A subserosus gócok esetében semmilyen fertilitást befolyásoló hatást nem sikerült igazolni $[14,15]$. Azok a közlemények, amelyekben a myomák méretfüggő hatásait vizsgálták, ilyen jellegü összefüggést nem találtak.

A későbbiekben említésre kerülő myomamútétek hatása, azok etikai háttere miatt, nehezen vizsgálható. Korlátozott számban elérhetók ilyen jellegú munkák, amelyek eredményei alapján a submucosus myomák eltávolításának fertilitásjavító hatása lehet, míg az intramuralis gócok eltávolításának szükségessége még kérdéses [14]. A méh üregét deformáló gócok méhtükrözés során történő eltávolítása Bettocchi munkája alapján is indokoltnak tûnik [16], míg Benecke vizsgálatai alapján az intramuralis myomák eltávolítása egyértelmúen javítja az asszisztált reprodukciós technikák eredményességét [17].

Metaanalízis során a myomák fertilitásra gyakorolt hatásáról egyértelmű, erős evidenciákat azonban nem sikerült felállítani [18].

\section{Alhasi diszkomfort, fájdalom, székelési, vizelési panaszok}

A myomák méretüktől, számuktól, elhelyezkedésüktől függően diverz alhasi panaszokat okozhatnak, a myomák és ezen panaszok közötti összefüggésekre egyértelmú adatok találhatók [19]. Teltségérzet, puffadás, alhasi fájdalom érzete csupán a daganat térfoglalása miatt alakulhat ki. Ha a hátsó falban, a végbél felé terjeszkednek, székürítési panaszokat, ha a hólyag felé terjedően találhatók, vizelettartási, vizeletürítési panaszokat, illetve gyakori vizelési ingert okozhatnak.

A myoma által okozott fájdalmas együttlét intenzívebb a fundusban, illetve a mellső falban elhelyezkedő gócoknál [20].

\section{Diagnosztika}

A myomák kezelése panaszmentes esetben nem szükséges. Terápiás terv felállításában az okozott panaszokon túl elhelyezkedésük, méretük, számuk is fontos tényező. A különböző képalkotó eljárások segítségével ezeket a kezeléshez szükséges paramétereket lehetséges vizsgálni. A myomairányú vizsgálatok során különös figyelemmel kell lenni a kisebb méretű myomákra is. A myomák elhelyezkedésének pontos leírása, azoknak a külső, illetve belső myometriumköpeny (endometriumtól, illetve se- rosai felszíntől való távolsága) meghatározása a későbbi mútétek során nagy segítség lehet.

Az ultrahangvizsgálat a képalkotók közül a legkézenfekvőbb módszer. Alacsony költségü, széles körben alkalmazott eljárás, amely részét képezi a rutin nőgyógyászati vizsgálatnak [21]. A myoma megjelenése általában jól körülírt, hypoechogen, gyakran aszimmetrikus terület. A kalcifikálódás, bevérzés hyperechogen területként, a központi szövetek fellágyulását követő cisztikus degeneráció echómentes területként ábrázolódik. Nagyméretü myoma(ák) esetében a hüvelyi és hasi ultrahangvizsgálatot szimultán érdemes végezni.

A szalinainfúziós ultrahangvizsgálat (SIS) során a méh üregébe juttatott sóoldat a méhen belüli elváltozások kontrasztosabb ábrázolását teszi lehetővé. A myomák esetében a méhưr deformitásának kérdésében ad választ a sófeltöltés [22].

Hasonló elv alapján segít a myoma lokalizációjának pontosabb megítélésében a hiszteroszalpingográfia (HSG). A módszer pontatlansága [23], a röntgensugár alkalmazása miatt azonban napjainkban már elavult módszernek tekinthető.

A mágneses rezonanciavizsgálat (MRI) igen pontos eljárás a myomák pontos elhelyezkedésének megítélésében. A beavatkozás költséges ugyan, de számos esetben a kezelés megtervezéséhez fontos, elengedhetetlen információkkal szolgál.

A diagnosztikus eljárások között kell megemlíteni a méhtükrözést, hiszteroszkópiát (HSC) is. A submucosus gócok pontos megítélésében, illetve abban, hogy az intramuralis gócok deformálják-e a méhürt, diagnosztikus HSC végzése során kapunk információt. A beavatkozás ambuláns körülmények között, anesztézia nélkül is elvégezhető [24]. A méhtükrözés nagy előnye a képalkotó eljárásokkal szemben, hogy a beavatkozás során nemcsak a diagnózis felállítására, hanem - a későbbiekben részletesen leírt módon - egyúttal a kezelésre is lehetőség van.

$\mathrm{Az}$ adenomyosis képalkotó vizsgálatokkal gyakran hasonló a myomákhoz. Ultrahangvizsgálat során az echogenitása hasonló, a méh diffúz megnagyobbodása utalhat adenomyosisra, míg az aszimmetrikus megnagyobbodás vagy a méhnyálkahártya abnormális elhelyezkedése myomára jellemzőbb. Áramlásos vizsgálat során adenomyosis esetében a terime belsejében, míg myomák esetében a képlet körül mérhető fokozott keringés. MRvizsgálattal a junctionalis zóna (JZ) vastagságának mérése ad támpontot a diagnózisban. A 12 mm-nél vaskosabb JZ adenomyosisra jellemző.

A leiomyosarcoma diagnosztikájában az ultrahangvizsgálat nem ad egyértelmú választ. Megjelenésükben a myomához hasonló elváltozások. Áramlási vizsgálat során mindkét elváltozás fokozott értékeket mutat. Differenciálásukban az MRI sem segít egyértelmúen, mindkét elváltozás hasonló megjelenésü.

A nem éles elhatárolódás, a szoliter megjelenés, a magasabb életkor, illetve a postmenopausában észlelt, gyors növekedést mutató terime a leiomyosarcoma felé billentik a mérleg nyelvét [25]. 


\section{Gyógyszeres terápia}

Az invazív beavatkozások elkerülése céljából számos konzervatív, gyógyszeres kezelésre van lehetőség. Fontos szem előtt tartani azonban, hogy ezek a kezelések a myomák méretét, az általuk okozott panaszokat (vérzés, nyomási panaszok) csökkenthetik ugyan, de a myomákat szanálni, végérvényesen gyógyítani nem képesek. Leggyakrabban a GnRH-analógok és az ulipristal acetát használatával és ezekkel gyújtött tapasztalatokkal találkozhatunk.

\section{GnRH-analógok}

A GnRH a hipofízis-petefészek tengelyre gyakorolt hatásával a petefészek hormontermelését gátolja. Ezáltal hat a hormondependens myomára is. A használata következtében egyértelmúen csökken a myoma mérete, és az általa okozott panaszok is csökkennek. Folyamatos alkalmazása a magas költségek és a nem kívánt hosszú távú mellékhatások (a csontsűrüség csökkenése) miatt nem lehetséges. Leginkább preoperatív használatát vizsgálták eddig, amely során mütét közben kevesebb vérzés, csökkent hospitalizálás igazolódott mind méheltávolítás, mind myomakiágyazás esetében. Mütét előtti alkalmazásának hátránya lehet, hogy a kisebb myomagócok, méretük csökkenése miatt, a beavatkozás során nehezen vagy egyáltalán nem azonosíthatóak. Másik hátrányként említhetjük, hogy a mütét során a myoma kiágyazása, a preparálás nehezített [26].

\section{Ulipristal acetát (UPA)}

Az ulipristal acetát egy szájon át szedhető, szelektív progeszteronreceptor-módosító molekula (SPRM), amely hatását a myomasejtek apoptózisának, illetve proliferációjának befolyásolásával fejti ki. Az UPA használatával kapcsolatban számos nemzetközi tanulmány érhető el. A PEARL I-IV. tanulmányok a gyógyszer hatását (I) [27], GnRHa-val történő összehasonlítását (II) [28], hosszú távú (III) [29], és ismételt kezeléseket (IV) [30] vizsgálják. Az irodalmi adatokból egyértelmú az UPA myomákra gyakorolt méretcsökkentő hatása, illetve a vérzéses, fájdalommal kapcsolatos panaszok mértékének szignifikáns csökkenése a kezelés alatt. A kezeléseket követően, illetve az ismételt kezelések szüneteiben megfigyelhető a myomaméretek, illetve az általuk okozott panaszok mértékének enyhe „visszaemelkedése”. Fontos megemlíteni az UPA méhnyálkahártyára gyakorolt hatását is, amelynek következtében egy speciális megjelenési forma, az SPRM által okozott elváltozás (progesterone receptor modulators-associated endometrial changes - PAECs) figyelhető meg. Az elváltozás a kezelés befejezését követően megszűnik, kóros vagy rosszindulatú méhnyálkahártya-elfajulás a kontrollcsoportoknak megfelelő arányban alakult ki, tehát az UPA-nak ilyen káros mellékhatása nem bizonyított [31]. A keze- lést követően létrejött terhességek vizsgálata a kis esetszám miatt még nem igazolja a kiegészítő sebészeti beavatkozás szükségességét [32]. Az UPA preoperatív használata a myomák konzisztenciájára, preparálhatóságára negatív hatással lehet, ebben az alkalmazásban kifejtett jótékony hatásáról egyértelmú irodalmi adatok nem elérhetőek.

\section{Radioterápia}

$\mathrm{Az}$ arteria uterina embolisatiója egy minimálisan invazív technika, amely során mindkét oldali, méhet ellátó verőeret polivinilalkohollal embolizálják. A gyógyszeres, illetve mütétes kezelés mellett a terápia egyik alternatívája lehet, amely Magyarországon kevésbé elterjedt [33]. A beavatkozás sikerességét angiográfia segítségével ellenőrzik. Az embolisatiót követően a méh vérellátása a vaginalis és ovarialis rendszer kollaterálisain keresztül rendeződik. A myoma vérellátása végartériából történik, ami az arteria uterinák lezárása után megszakad [34]. A myomák mérete és az általuk okozott panaszok is csökkenhetnek. Kifejezetten nagy méretű myomák és vérzészavar, fájdalom esetén lehet helye az eljárásnak a kezelésben [35]. Meddőség, ismételt vetélés kapcsán elvégzett beavatkozásokkal is találkozhatunk az irodalomban, illetve leírnak embolisatio után fogant és kihordott terhességet is [36]. Hosszú távú szövődményként a korai petefészek-kimerülés, infekció, amely későbbi petevezetőfunkció-vesztéssel meddőséghez vezethet, terhesség alatti méhruptura, illetve a placenta keringésének zavara figyelhető meg [37].

A betegelégedettséget tekintve egyértelmű erős evidencia nem szól sem az embolisatio, sem a sebészeti beavatkozás (myomakiágyazás, méheltávolítás) mellett. A későbbi teherbe esés nagy áttekintő tanulmány alapján a mütétes megoldás után tünik valószínúbbnek, de emellett sem szólnak egyértelmú bizonyítékok. A gyorsabb felépülés, a kevesebb, munkától távol töltött idő egyértelmúen az embolisatio oldalára billenti a mérleg nyelvét. A komplikációkat tekintve sincs a beavatkozások között számottevő különbség, azonban az embolisatiót követően szükségessé váló mútétek magasabb aránya (15-32\%) miatt a költség-hatékonysági számítások szerint a mütétes megoldás túnik hasznosabbnak [38].

\section{Sebészi kezelés}

A myomák mint jóindulatú daganatok kezelésében a gyógyszeres és radiológiai kezelések mellett definitív megoldásként a sebészeti kezelés lehetséges. A myomák kezelésében ez az egyetlen módszer, amely a myoma mint panaszt okozó elváltozás vagy a myomás méh eltávolításra kerül. Lehetőség van a myomák kiágyazására, elhelyezkedéstől függően a méh ürege felőli (méhtükrözés), illetve a hasüreg felőli megoldásra, amely történhet hastükrözéssel és hasmegnyitással is. Amennyiben a góc, gócok kiágyazása nem lehetséges és lezárt a családterve- 
zés, a myomás méh eltávolítása is szóba jöhet laparoszkópos, nyitott hasi és hüvelyi mútét során. A mütéti megoldást megelőzően különösen fontos a myomák pontos preoperatív kivizsgálása, képalkotó vizsgálata a méretek, elhelyezkedés és ezek alapján a pontos műtéti terv felállítása szempontjából. A myomák eltávolítása endoszkópia vagy laparotomia útján lehetővé teszi a korábban ilyen javallat alapján nagy számban végzett, nagy megterheléssel és a kismedencei anatómiai viszonyok nagymértékű változásával járó méheltávolítások gyakoriságának csökkentését.

\section{Hiszteroszkópia}

A méhtükrözés (hiszteroszkópia) számára hozzáférhető és eltávolítható myomák a FIGO-beosztás szerinti 0, I, II-es elhelyezkedésû gócok. Ezen elhelyezkedésû gócok mindig deformálják a méh üregét, így a vérzéses és meddőségi panaszok [14] hátterében nagy valószínűséggel oki tényezőként szerepelnek. Transcervicalis myomareszekció során a méh ürege felől történik a myoma eltávolítása, amely a mérettől függően gyakran két ülésben kivitelezhető [39]. A reszekció szem ellenőrzése mellett zajlik, így a teljes eltávolítás biztonsággal ellenőrizhető. Mono- és bipoláris eszközök használata mellett a hagyományos ollóval történő preparálás is választható eljárás, fokozottan figyelve a megfelelő disztendáló médium kiválasztására. A beavatkozás során a góc eltávolítása egyben vagy szeletekben történik [40]. Nagyméretü myomák esetében gyakran előfordul, hogy a góc méhüregbe domborodó nagyobb része kerül eltávolításra első mütétnél, majd egy-két ciklust követően újabb ülésben a maradék, ekkor már szintén a méh ürege felé türemkedő részének eltávolítása lehetséges [41]. A technikai fejlesztéseknek köszönhetően lehetőség nyílt a kisebb méretű gócok ambuláns módon, anesztézia nélküli eltávolítására is. A myoma bipoláris eszközzel történő felszeletelését követően a kisebb szövetrészletek a nyakcsatornán keresztül tágítás nélkül eltávolíthatóak [24]. Egy olasz munkacsoport olyan új módszert dolgozott ki (OPPIuM) [42], amelynek segítségével a mélyen ülő nagy myomák office hiszteroszkópos bemetszését követően a myoma a méh ürege felé türemkedik. Ezt követően a hagyományos eljárással történő reszekció során már egy ülésben kivitelezhető a teljes kiágyazás. Az egyszerúbb, rövidebb beavatkozások eléréséhez méhen belüli morcellátorok állnak rendelkezésre mind a hagyományos, mind az office hiszteroszkópos változathoz [43]. A panaszok mütét utáni alakulását számos tanulmány vizsgálta. A vérzészavarok nagymértékű javulása egyértelmű az adatokból, a meddőségre gyakorolt jótékony hatása még nem nyert bizonyítást [44]. A beavatkozás szövődményei között igen alacsony számban találkozhatunk méhperforációval, leggyakoribb szövődménynek az egyéb méhen belüli beavatkozásokat követően is fellépő adhéziók kialakulása számít. Ennek kiküszöbölésére adhéziógátló barrierek alkalmazása vagy rövid idővel a mútétet követő office hiszteroszkópia alkalmazható, amely során a kezdődő, kialakuló szálagos összenövések oldása lehetséges, akár több ülésben is [45].

\section{Laparoszkópia, laparotomia}

A myomagócok hasüreg felőli kiágyazására endoszkópos és nyitott hasi mútét során is lehetőség nyílik. A mütét típusának megválasztásakor több tényezőt is figyelembe kell venni. Talán legfontosabb az endoszkópos beavatkozás tárgyi és személyi feltételei. Ezenkívül meghatározó a myomák száma (3 felett nyitott mütét javasolt), elhelyezkedése és mérete [46]. A megfelelő feltételek mellett végzett endoszkópos, illetve hasi úton végzett beavatkozások szövődményeinek, hatásainak vizsgálatára számos tanulmány született. Az endoszkópia ismert előnyei itt is érvényesülnek: kevesebb a mütét során a vérvesztés, gyorsabb a felépülés, kisebb a posztoperatív fájdalom [47]. A panaszok csökkenésében, a mútét utáni reproduktív mutatókban különbség egyik típus javára sem figyelhető meg [48]. A mútéti idő, különösen a tanuló fázisban, az endoszkópos eljárásoknál hosszabb, azonban minden körülményt figyelembe véve megfelelő kondíciók mellett a laparoszkópos mód az előnyösebb. Mütéttechnikailag a kiágyazás történhet hagyományos ollóval preparálással és elektrosebészeti eszközökkel is. A monopoláris eszköz és a harmonic eszköz használatát összehasonlító tanulmány szerint az utóbbi használatával kisebb a mútét alatti vérvesztés [49]. A sebágy zárása mélységtől függően egy vagy több rétegben, illetve csomós vagy tovafutó öltésekkel történhet. Laparoszkópia során alkalmazható az intra- és az extracorporalis csomózás is. A laparoszkópia során kiágyazott myoma hasüregből történő eltávolítása colpotomián keresztül vagy morcellátor alkalmazásával lehetséges. A myoma darabolása egyrészt direkt sérülés lehetőségét rejti magában, másrészt a váratlan szövettani eredményü tumor tovaterjedésének veszélyét hordozza. Habár az Egyesült Államokban egy sajnálatos eseményt követően 2014 áprilisában a Food and Drug Administration (FDA) betiltotta a morcellátorok használatát, számos tanulmány adatai alapján kijelenthetjük, hogy egyértelmü bizonyíték nem szól ezen eszközök használata ellen [4].

A ritkán előforduló szövődmények között leggyakoribb a későbbi terhességek során előforduló méhruptura, amelynek hátterében az elektrosebészeti módszerek túlzott használata állhat [50].

A célzott, myoma eltávolítására irányuló mútétes beavatkozások csökkenthetik a világszerte igen nagy számban elvégzett csonkító mútét, a méheltávolítás gyakoriságát.

\section{Következtetés}

Elmondható, hogy a myomák kezelése személyre szabott, igen körültekintő kell legyen. A kivizsgálás során a panaszoknak, azok mértékének feltárása, a képalkotó 
vizsgálatokkal a myomák számának, méretének és elhelyezkedésének pontos meghatározása a későbbi kezelés módjának kiválasztásában elengedhetetlen. A vérzészavarok, fájdalom csökkentésében a konzervatív kezelések is szóba jönnek, azonban a myomák definitív kezelése csak sebészi úton oldható meg.

Anyagi támogatás: A közlemény megírása anyagi támogatásban nem részesült.

Szerzői munkamegosztás: T. P: A téma felvetése. T. P., P. R.: A kézirat megszövegezése. A cikk végleges változatát mindkét szerző elolvasta és jóváhagyta.

Érdekeltségek: A szerzőknek nincsenek érdekeltségeik.

\section{Irodalom}

[1] Luoto, R., Kaprio, J., Rutanen, E. M., et al.: Heritability and risk factors of uterine fibroids - the Finnish Twin Cohort Study. Maturitas, 2000, 37(1), 15-26.

[2] Parker, W. H.: Etiology, symptomatology, and diagnosis of uterine myomas. Fertil. Steril., 2007, 87(4), 725-736.

[3] Walker, C. L., Stewart, E. A.: Uterine fibroids: the elephant in the room. Science, 2005, 308(5728), 1589-1592.

[4] Brölmann, H., Tanos, V., Grimbizis, G., et al.: Options on fibroid morcellation: a literature review. Gynecol. Surg., 2015, 12(1), 3-15.

[5] Fusi, L., Cloke, B., Brosens, J. J.: The uterine junctional zone. Best Pract. Res. Clin. Obstet. Gynaecol., 2006, 20(4), 479-491.

[6] Cramer, S., Patel, A.: The frequency of uterine leiomyomas. Am. J. Clin. Pathol., 1990, 94(4), 435-438.

[7] Drayer, S. M., Catherino, W. H.: Prevalence, morbidity, and current medical management of uterine leiomyomas. Int. J. Gynecol. Obstet., 2015, 131(2), 117-122.

[8] Khan, A. T., Shehmar, M., Gupta, J. K.: Uterine fibroids: current perspectives. Int. J. Womens Health, 2014, 6, 95-114.

[9] Michnovicz, J. J., Hershcopf, R. J., Naganuma, H., et al.: Increased 2-hydroxylation of estradiol as a possible mechanism for the anti-estrogenic effect of cigarette smoking. N. Engl. J. Med., 1986, 315(21), 1305-1309.

[10] Gupta, S., Jose, J., Manyonda, I.: Clinical presentation of fibroids. Best Pract. Res. Clin. Obstet. Gynaecol., 2008, 22(4), 615-626.

[11] Ryan, G. L., Syrop, C. H., Van Voorhis, B. J.: Role, epidemiology, and natural history of benign uterine mass lesions. Clin. Obstet. Gynecol., 2005, 48(2), 312-324.

[12] Donnez, J., Jadoul, P.: What are the implications of myomas on fertility? A need for a debate? Hum. Reprod., 2002, 17(6), 1424-1430.

[13] Devi Wold, A. S., Pham, N., Arici, A.: Anatomic factors in recurrent pregnancy loss. Semin. Reprod. Med., 2006, 24(1), 25-32.

[14] Pritts, E. A., Parker, W. H., Olive, D. L: Fibroids and infertility: an updated systematic review of the evidence. Fertil. Steril., 2009, 91(4), 1215-1223.

[15] Cook, H., Ezzati, M., Segars, J. H., et al.: The impact of uterine leiomyomas on reproductive outcomes. Minerva Ginecol., 2010, $62(3), 225-236$.

[16] Bettocchi, S., Siristatidis, C., Pontrelli, G., et al.: The destiny of myomas: should we treat small submucous myomas in women of reproductive age? Fertil. Steril., 2008, 90(4), 905-910.

[17] Benecke, C., Kruger, T. F., Siebert, T. I., et al.: Effect of fibroids on fertility in patients undergoing assisted reproduction. A structured literature review. Gynecol. Obstet. Invest., 2005, 59(4), $225-230$
[18] Metwally, M., Cheong, Y. C., Horne, A. W.: Surgical treatment of fibroids for subfertility. Cochrane Database Syst. Rev., 2012, 11, CD003857.

[19] Lippman, S. A., Warner, M., Samuels, S., et al.: Uterine fibroids and gynecologic pain symptoms in a population-based study. Fertil. Steril., 2003, 80(6), 1488-1494.

[20] Ferrero, S., Abbamonte, L. H., Giordano, M., et al.: Uterine myomas, dyspareunia, and sexual function. Fertil. Steril., 2006, $86(5), 1504-1510$

[21] Jakab, A. Jr., Ovári, L., Jubász, B., et al.: Ultrasound diagnosis of focal intrauterine lesions. [Méhen belüli körülírt elváltozások ultrahang-diagnosztikája.] Orv. Hetil., 2002, 143(29), 17391743. [Hungarian]

[22] Berridge, D. L., Winter, T. C.: Saline infusion sonohysterography: technique, indications, and imaging findings. J. Ultrasound. Med., 2004, 23(1), 97-112.

[23] Saravelos, S. H., Cocksedge, K. A., Li, T. C.: Prevalence and diagnosis of congenital uterine anomalies in women with reproductive failure: a critical appraisal. Hum. Reprod. Update, 2008, $14(5), 415-429$.

[24] Török, P., Major, T.: Office hysteroscopy: a new examination method in gynecological practice. [Office hiszteroszkópia - új vizsgálati lehetőség a nőgyógyászati gyakorlatban.] Orv. Hetil., 2011, 152(2), 51-54. [Hungarian]

[25] Dueholm, M., Lundorf, E., Hansen, E. S., et al.: Magnetic resonance imaging and transvaginal ultrasonography for the diagnosis of adenomyosis. Fertil. Steril., 2001, 76(3), 588-594.

[26] Lethaby, A., Vollenhoven, B., Sowter, M.: Pre-operative GnRH analogue therapy before hysterectomy or myomectomy for uterine fibroids. Cochrane Database Syst. Rev., 2000, 2, CD000547.

[27] Donnez, J., Tatarchuk, T. F., Bouchard, P., et al.: Ulipristal acetate versus placebo for fibroid treatment before surgery. N. Engl. J. Med., 2012, 366(5), 409-420.

[28] Donnez, J., Tomaszewski, J., Vázquez, F., et al.: Ulipristal acetate versus leuprolide acetate for uterine fibroids. N. Engl. J. Med., 2012, 366(5), 421-432.

[29] Donnez, J., Vázquez, F., Tomaszewski, J., et al.: Long-term treatment of uterine fibroids with ulipristal acetate. Fertil. Steril., 2014, 101(6), 1565-1573.e18.

[30] Donnez, J., Hudecek, R., Donnez, O., et al.: Efficacy and safety of repeated use of ulipristal acetate in uterine fibroids. Fertil. Steril., 2015, 103(2), 519-527.e3.

[31] Williams, A. R., Bergeron, C., Barlow, D. H., et al.: Endometrial morphology after treatment of uterine fibroids with the selective progesterone receptor modulator, ulipristal acetate. Int. J. Gynecol. Pathol., 2012, 31(6), 556-569.

[32] Luyckx, M., Squifflet, J. L., Jadoul, P., et al.: First series of 18 pregnancies after ulipristal acetate treatment for uterine fibroids. Fertil. Steril., 2014, 102(5), 1404-1409.

[33] Szabó, E., Nagy, E., Morvay, Z., et al.: Uterine arterial embolization for the conservative management of leiomyoma. [A leiomyoma konzervatív kezelése az arteria uterina embolisatiójával.] Orv. Hetil., 2001, 142(13), 675-680. [Hungarian]

[34] Ravina, J. H, Ciraru-Vigneron, N., Herbreteau, D., et al.: Arterial embolization to treat uterine myomata. Lancet, 1995, 346(8976), 671-672.

[35] Walker, W. J., Pelage, J. P.: Uterine artery embolisation for symptomatic fibroids: clinical results in 400 women with imaging follow up. BJOG, 2002, 109(11), 1262-1272.

[36] Goldberg, J., Pereira, L., Berghella, V., et al.: Pregnancy outcomes after treatment for fibromyomata: uterine artery embolization versus laparoscopic myomectomy. Am. J. Obstet. Gynecol., 2004, 191(1), 18-21.

[37] Mara, M., Kubinova, K.: Embolization of uterine fibroids from the point of view of the gynecologist: pros and cons. Int. J. Womens Health, 2014, 6, 623-629. 
[38] Gupta, J. K., Sinha, A., Lumsden, M. A., et al.: Uterine artery embolization for symptomatic uterine fibroids. Cochrane Database Syst. Rev., 2014, 12, CD005073.

[39] Birinyi, L., Kalamász, N. Z., Major, T., et al.: Evaluation of results in transcervical hysteroscopic myoma resection. [Transcervicalis myomaresectiók eredményeinek elemzése beteganyagunkban.] Orv. Hetil., 2002, 143(49), 2735-2740. [Hungarian]

[40] Vercellini, P., Zàina, B., Yaylayan, L., et al.: Hysteroscopic myomectomy: long-term effects on menstrual pattern and fertility. Obstet. Gynecol., 1999, 94(3), 341-347.

[41] Loffer, F. D.: Removal of large symptomatic intrauterine growths by the hysteroscopic resectoscope. Obstet. Gynecol., 1990, $76(5), 836-840$.

[42] Bettocchi, S., Di Spiezio Sardo, A., Ceci, O., et al.: A new hysteroscopic technique for the preparation of partially intramural myomas in office setting (OPPIuM technique): A pilot study. J. Minim. Invasive Gynecol., 2009, 16(6), 748-754.

[43] Connor, M.: New technologies and innovations in hysteroscopy. Best Pract. Res. Clin. Obstet. Gynaecol., 2015, 29(7), 951-965.

[44] Di Spiezio Sardo, A., Mazzon, I., Bramante, S., et al.: Hysteroscopic myomectomy: a comprehensive review of surgical techniques. Hum. Reprod. Update, 2008, 14(2), 101-119.

[45] Yang, J. H., Chen, M. J., Wu, M. Ү., et al.: Office hysteroscopic early lysis of intrauterine adhesion after transcervical resection of multiple apposing submucous myomas. Fertil. Steril., 2008, $89(5), 1254-1259$.

[46] Sizzi, O., Rossetti, A., Malzoni, M., et al.: Italian multicenter study on complications of laparoscopic myomectomy. J. Minim. Invasive Gynecol., 2007, 14(4), 453-462.

[47] Jin, C., Hu, Y., Chen, X. C., et al.: Laparoscopic versus open myomectomy - a meta-analysis of randomized controlled trials. Eur. J. Obstet. Gynecol. Reprod. Biol., 2009, 145(1), 14-21.

[48] Palomba, S., Zupi, E., Falbo, A., et al.: A multicenter randomized, controlled study comparing laparoscopic versus minilaparotomic myomectomy: reproductive outcomes. Fertil. Steril., 2007, $88(4), 933-941$.

[49] Litta, P., Fantinato, S., Calonaci, F., et al.: A randomized controlled study comparing harmonic versus electrosurgery in laparoscopic myomectomy. Fertil. Steril., 2010, 94(5), 1882-1886.

[50] Parker, W. H., Einarsson, J., Istre, O., et al.: Risk factors for uterine rupture after laparoscopic myomectomy. J. Minim. Invasive Gynecol., 2010, 17(5), 551-554.

(Török Péter dr., Debrecen, Nagyerdei krt. 98., 4032 e-mail: drtorokp@freemail.hu)

\section{A rendezvények és kongresszusok híranyagának leadása}

a lap megjelenése előtt legalább 40 nappal lehetséges, a 6 hetes nyomdai átfutás miatt. Kérjük megrendelőink szíves megértését.

A híranyagokat a következő címre kérjük: Orvosi Hetilap titkársága: Budai.Edit@akkrt.hu Akadémiai Kiadó Zrt. 